\title{
Pod set and Pollen Viability Studies in Yard Long Bean (Vigna unguiculata sub sp. sesquipedalis)
}

\author{
Merin, E.G.*, Sarada, S. and Celine, V.A. \\ Department of Olericulture, College of Agriculture, Vellayani- 695 522, Kerala. \\ Corresponding author email: merinelzageorge5010@gmail.com
}

\begin{abstract}
A study was conducted in a yard long bean (Vigna unguiculata sup/ssp. sesquipedalis) hybrid VS 50 (Kakkamoola Local) x VS 26 (Vellayani Jyothika) to assess the percentage fruit set at two time intervals and to identify the best time interval for pollination in yard long bean hybrids. Hand pollination was done using VS 50 as female parent and VS 26 as male parent for seven consecutive days at two time intervals, $6.30-7.30$ am and 7.30 8.30 am. Higher percentage of fruit set $(36.8 \%)$ was observed between 6:30 - 7:30 a.m. as compared to the time interval 7:30 - 8:30 am. (23.8\%). Pollen viability was determined for the parents VS 50 (Kakkamoola Local) and VS 26 (Vellayani Jyothika) at 6.30, 7.30 and $8.30 \mathrm{am}$. Highest pollen viability for both the parents VS 50 and VS 26 was observed during $7.30 \mathrm{am}$. The present study shows that the best time interval for crossing in yard long bean is $6.30-7.30$ a.m.
\end{abstract}

Keywords: Hybridization, Pod set, Pollen viability and Vigna unguiculata sub sp. sesquipedalis

\section{INTRODUCTION}

Vigna unguiculata sub sp. sesquipedalis (L.) Verdcourt commonly known as yard long bean or pole type vegetable cowpea is a commercially used leguminous plant with very long pods and climbing growth habit, widely grown in China, South and South East Asia. It belongs to the family Fabaceae and is one of the most popular and remunerative vegetable crop traditionally grown in Kerala, cultivated mainly for crisp and tender pods that are consumed both fresh and cooked. It is a rich and inexpensive source of vegetable protein and its cultivation enriches soil fertility by fixing atmospheric nitrogen. It has become an essential component of sustainable agriculture in marginal lands of the tropics because of its quick growth habit.

Productivity of the crop is limited by a complexity of biotic (pest and diseases) and abiotic (rainfall, temperature, relative humidity and light intensity) factors. Some attempts have been made to study the genetic and environment variability for various productive traits, inheritance of these traits and correlation between yield and its components. So far no public sector hybrids of yard long bean are available for cultivation in Kerala, which makes farmers to depend on private sector hybrids by paying exorbitant prices. So there is an urgent need to improve the crop for better yield and quality through heterosis breeding. Cultivar improvement in selfpollinated species is done by hybridization. Because of poor crossing success and less number of seeds per pod, heterosis is difficult. Pod yield and yield attributes in vegetable cowpea are complex traits governed by polygenic inheritance, affected by environment. Both genotype and environment affect the crossing success in self-pollinated species such as vegetable cowpea.

Cowpea is highly self - pollinated, the result of a cleistogamous flower structure and Simultaneous pollen shed and stigma receptivity (Ehlers and Hall, 1997), although some crossing may occur due to insects. Self-pollinated nature is due to hermaphrodite sex form, homogamy and dehiscence of anther much earlier than anthesis. Stamens and pistil in opened flower remain enveloped together inside the tube like structure of joined petals called as Keel, leading to cleistogamous nature. Flowers open only once between 7.00 and 9.00 a.m. On cloudy days the flowers may open even in the afternoon. Anther dehiscence is influenced by environmental factors 
such as clear sky, presence of moonlight, warm temperature etc. and it may vary from $10.00 \mathrm{pm}$. at night to $1.00 \mathrm{am}$. Stigma become receptive and pollen become fertile on the day of anthesis. Several hybridization procedures have been developed (Rachie et al. 1975; Blackhurst and Miller 1980). High hybrid pod set is observed when emasculation is done before anthesis which is followed by pollination on the day of anthesis in morning hours. Rachie et al. (1975) reported that some cowpea genotypes are superior pollen donors as compared to others which are seed parents. Time and efforts in crossing play an important role in expressing efficient parental donors for crossing.

The cross VS $50 \times$ VS 26, identified as a superior hybrid for yield and quality, was used for the present study. The aim of the study was to observe the percentage fruit set at two time intervals in the yard long bean hybrid VS $50 \times$ VS 26 and the influence of pollen viability of the parents at different times on fruit set, in order to identify the best time interval for pollination in yard long bean hybrids. Resmi and Gopalakrishnan (2004) reported problems such as delayed and erratic flowering and low pod set in yard long bean.

The study was conducted at the Department of Olericulture, College of Agriculture, Vellayani during February to March 2017. Lakshmi (2016) conducted a diallel analysis to study the heterosis and combining ability of yard long bean (Vigna unguiculata subsp. sesquipedalis (L.) Verdcourt) and to develop superior hybrids with high yield and quality. Based on the mean performance, specific combining ability and standard heterosis, the hybrid VS $50 \times$ VS 26 (Kakkamoola Local x Vellayani Jyothika) was observed to be one of the most promising for yield and quality characters. With this background, the cross VS 50 x VS 26 (Kakkamoola Local x Vellayani Jyothika) was selected for the study. The source and characters of the parents VS 50 and VS 26 are given in Table 1.
Hand pollination was done using VS 50 as female parent and VS 26 as male parent for seven consequetive days at two time intervals, $6.30-7.30$ a.m. and 7.30 - 8.30 a.m. Ige et al. (2011) studied the floral biology and pollination ecology of three varieties of cowpea (Vigna unguiculata L. Walp.) and observed that flower opening is initiated between 6.00 to 6.30 am and closes between 11.30 to 12.00 $\mathrm{pm}$. in all the varieties and that when the weather is hot and dry the flowers close earlier.

Pollen viability was determined for the parents VS 50 (Kakkamoola Local) and VS 26 (Vellayani Jyothika) at $6.30,7.30$ and $8.30 \mathrm{am}$. Flower bud due to open the next day, was selected in the female parent (VS 50). Emasculation was done in the afternoon hours by removing the keel petal. Cowpea flowers drop off easily as they are highly sensitive. Hence butter paper bag was used to cover the bud and to prevent drying out of emasculated bud. Pollen was collected next day morning from a freshly opened flower. The standards and wings from the intended male parent (VS 26) was removed and by slight depression of the keel, the stigma covered with the pollen grains protrudes out which itself can be used as brush for pollination. It was brushed on the stigmatic surface of the emasculated flower. The crossed flowers were covered and labeled.

Pollen viability was determined by acetocarmine staining method. Anthers were collected from a minimum of 3 mature flowers per plant at $6.30 \mathrm{am}$. One drop of $1 \%$ acetocarmine was placed on a slide glass. Pollen grains were mounted slightly in a drop of acetocarmine: glycine (1:1). The slides were left for 30 minutes for proper staining. A cover slip was placed gently over the slide and examined under a microscope. Pollen viability was studied by counting the number of stained pollen grains and unstained, aborted pollen grains. An average of 100 pollen were counted in different microscopic fields. The above procedure was repeated at 7.30 and $8.30 \mathrm{am}$. for both the parents.

Table 1: Source and characters of parents used for the study

\begin{tabular}{llll}
\hline Parent & Name of Accession & Source & Character \\
\hline VS 50 & Kakkamoola Local & $\begin{array}{l}\text { Kakkamoola, } \\
\text { Thiruvananthapuram, Kerala }\end{array}$ & High yield, long pods \\
\hline VS 26 & Vellayani Jyothika & $\begin{array}{l}\text { College of Agriculture, } \\
\text { Vellayani, Kerala }\end{array}$ & High yield, long pods \\
& & & \\
\hline
\end{tabular}


The number of pods that set on hand pollination was counted and recorded. Percentage of pod set was calculated using total number of crosses done. Pollen viability was calculated as follows:

Pollen viability $\%=$

Number of well filled and stained pollen grains x 100 Total number of pollen grains counted
The data on percentage of pod set in the cross VS $50 \times$ VS 26 is presented in Table 2. Higher percentage of fruit set $(36.8 \%)$ was observed in the cross VS $50 \mathrm{x}$ VS 26 between 6:30 - 7:30 am. as compared to the time interval 7:30 - 8:30 am. (23.8\%). According to Ehlers and Hall (1997), pollinations performed after $10 \mathrm{am}$. are less successful than pollinations performed between 7- $10 \mathrm{am}$. Rachie et al. (1975) reported an average success of 10-20\% in cowpea pollination.

Table 2: Percentage of pod set in the cross VS 50 x VS 26

\begin{tabular}{|c|c|c|c|c|}
\hline \multirow{3}{*}{ Days } & \multicolumn{4}{|c|}{ Time interval } \\
\hline & \multicolumn{2}{|c|}{ 6: 30 - 7:30 a.m. } & \multicolumn{2}{|c|}{ 7:30 - 8:30 a.m. } \\
\hline & No. of crosses & Pod set & No. of crosses & Pod set \\
\hline 1 & 5 & 2 & 7 & 1 \\
\hline 2 & 5 & 1 & 4 & 2 \\
\hline 3 & 8 & 3 & 7 & 1 \\
\hline 4 & 5 & 2 & 8 & 2 \\
\hline 5 & 5 & 2 & 7 & 2 \\
\hline 6 & 6 & 3 & 5 & 1 \\
\hline 7 & 4 & 1 & 4 & 1 \\
\hline Total & 38 & 14 & 42 & 10 \\
\hline Pod set $(\%)$ & \multicolumn{2}{|c|}{36.8} & \multicolumn{2}{|c|}{23.8} \\
\hline
\end{tabular}

Pollen viability of the parents VS 50 and VS 26, determined at 6.30, 7.30 and $8.30 \mathrm{a} . \mathrm{m}$. is given in Table 3. Highest pollen viability for both the parents VS 50 and VS 26 was observed during 7.30 a.m. Warrag and Hall (1983) and Faisal et al. (1992) attributed low pod set in cowpea to low pollen viability and anther dehiscence. Animasaun (2014) reported that fruit set in plants is determined to a greater extent by the amount of viable pollen in a flower. The present study showed that the best time interval for crossing in yard long bean is 6.30- 7.30 a.m.

Table 3: Percentage of Pollen viability

\begin{tabular}{|c|c|c|}
\hline \multirow{2}{*}{ Time } & \multicolumn{2}{|c|}{ Pollen viability (\%) } \\
\cline { 2 - 3 } & VS 50 & VS 26 \\
\hline 6.30 a.m. & 86.50 & 90.90 \\
\hline 7.30 a.m. & 89.50 & 93.00 \\
\hline 8.30 a.m. & 88.50 & 88.50 \\
\hline
\end{tabular}




\section{REFERENCES}

Animasaun, D. A., Oyedeji, S., Azeez, M.A. and Onyegwukwu, F. 2014. Evaluation of growth and pollen viability in relation to fruit set among five varieties of tomato grown in Nigeria. Agronomski glasnik: Glasilo Hrvatskog agronomskog društva, 76(4-5):203-218.

Blackhurst, H.T., and J.C. Miller, Jr. 1980. Cowpea. In: W.R Fehr and H. H Hadley (eds.), Hybridisation of crop plants. Univ. of Wisconsin, Madison. p. 327-337.

Ehlers, J.D. and Hall, A. E. 1997.Cowpea (Vigna unguiculata L. Walp.). Field Crops Res. 53: 187- 204.

Faisal, E. A., Anthony, E. H. and Darleen, A. D. 1992. Heat injury during floral development in cowpea (Vigna unguiculata, Fabaceae). Am. J. Bot. 79 (7): 784-791.

Ige, O.E., Olotuah, O.F. and Akerele, V. 2011. Floral biology and pollination ecology of cowpea
(Vigna unguiculata L. Walp). Mod. Appl. Sci. 5(4): 74- 82.

Lakshmi, K.M. 2016. Development of hybrids in yard long bean (Vigna unguiculata subsp. sesquipedalis (L.) Verdcourt). MSc (Hort) thesis, Kerala Agricultural University, Thrissur, 115p.

Rachie, K.O., Rawal, K. and Franckowiak, J.D. 1975. A rapid method of hand crossing cowpeas. Technical Bulletin No. 1. International Institute of Tropical Agriculture, Ibadan, Nigeria.

Resmi, R. and Gopalakrishnan, T.R. 2004. Effect of plant growth regulators on the performance of yard long bean. J. Trop. Agric. 42 (1-2): 5557.

Warrag and Hall. 1983. Reproductive responses of cowpea to heat stress: genotypic differences in tolerance to heat at flowering. Crop Sci.23: 1088-1092.

(Received on 30.9.2017, Revised on 6.12.2019 and accepted on 12.12.2019) 